sex-determination in plants, and elucidated the nature of polyploidy. One remarkable success based on keen observation and appropriate experimentation was to demonstrate the balanced lethal situation established in the 'ever-sporting Stocks'. $\mathrm{He}$ has contributed much to the clarification of linkage groups in Pisum, and his recent work proving sexual reproduction in the yeasts is of fundamental importance for the genetics of micro-organisms.

\section{James Alfred Ewing Medal Awarded to Sir Clifford Paterson, O.B.E., F.R.S.}

ON the joint recommendation of the presidents of the Royal Society and the Institution of Civil Engineers, the Council of the Institution of Civil Engineers has awarded the James Alfred Ewing Medal for 1946 to Sir Clifford Paterson, for specially meritorious contributions to the science of engineering in the field of research. The medal is awarded annually and was founded in 1936 in memory of Sir Alfred Ewing. Sir Clifford Paterson is in charge of the Research Laboratory of the General Electric Co. Ltd., Wembley, Middlesex. His contributions to the science of engineering in the field of research have extended over forty-five years. His work has been particularly outstanding in the development of new sources of illumination, in the study of their use and in their precision measurement. This work was carried out at the National Physical Laboratory until 1919 and later continued after he had joined the General Electric Co. More recently he has co-ordinated the work of numerous teams in connexion with outstanding developments in the use of high radio frequencies, thus making possible many of the vital new weapons of defence and offence. The production of special devices and particularly of new valves in quantity, at many stages of the War, kept our Services ahead of those of the enemy.

\section{Royal Aeronautical Society Awards}

THe following medals have been awarded by the Council of the Royal Aeronautical Society :

Simms Gold Medal : awarded annually for the best paper read in any year before the Society on any science allied to aeronautics, such as meteorology, wireless telegraphy, instruments, to Prof. L. Aitchison, professor of industrial metallurgy, University of Birmingham ;

George Taylor (of Australia) Gold Medal : awarded annually, at the discretion of the Council, for the most valuable paper submitted or read during the previous session, to Prof. A. R. Collar, Sir George White professor of aeronautical engineering, University of Bristol ;

Wakefield Gold Medal: awarded annually to a member or non-member, to the designer of any invention or apparatus tending towards safety in flying, to Mr. Edwin Link, inventor of the 'Link trainer';

Society's Silver Medal : awarded, at the discretion of the Council, for an advance in aeronautical design, to Mr. W. G. Garter, chief designer, Gloster Aircraft Co., Ltd., for his work on the development and design of jet-propelled aircraft.

R.38 Memorial Prize : offered annually for the best paper received by the Society on some subject of a technical nature in the science of aeronautics, preference being given to papers which relate to airships, to Mr. J. K. Hardy, of the Royal Aircraft Establishment ;
Edward Busk Memorial Prize: offered annually for the best paper received by the Society on some subject of a technical nature in connexion with aeroplanes (including seaplanes), to Mr. J. Smith, chief designer, Vickers Armstrongs, Ltd., Supermarine Works.

\section{University of Glasgow: Freshwater Biological Laboratory and Insect Field Station}

IMPORTANT additions to the facilities available at the University of Glasgow for research and teaching in the field have recently been made available by the erection of two former Government huts on the shores of Loch Lomond, on a site kindly provided by Sir Iain Colquhoun, Bt., of Luss, and only some twenty miles distant from the University. The freshwater work is under the care of Dr. H. D. Slack, lecturer in freshwater biology, who has charge of one hut together with a motor-boat and dinghy. For the first time, continuous investigations can be carried out on the biology of freshwaters in Scotland, and the great size and exceptional depth of Loch Lomond render it an admirable site for such work. A generous gift of money by Sir Harold Bowden, Bt., for entomological research over a period of seven years, with particular reference to the biology of midges, is responsible for the erection and equipment of the second hut, and for the appointment of two research assistants who work under the direction of Mr. J. A. Downes, lecturer in entomology. The money is being shared with the Department of Natural History, University College, Dundee (University of St. Andrews), where the biology of Monomorium together with certain aspects of the midge problem are being studied by Prof. A. D. Peacock and assistants. This opportunity of cooperation between two Universities is particularly appreciated. The work of both centres is being co-ordinated with that of the Committee on the Control of Midges appointed by the Department of Health for Scotland. The Insect Field Station is also being used as a centre for the teaching of insect ecology. The University of Glasgow is thus in the fortunate position of being able to conduct field classes in freshwater biology and in insect ecology at Loch Lomond, and also to avail itself of the rapidly increasing facilities for marine biology available at the Millport Laboratory of the Scottish Marine Biological Association on the Clyde.

\section{Further Education}

IT is the custom to greet a new magazine by asserting, often with more courtesy than truth, that it will fulfil a long-felt need. No such formula need apply to Further Education, published by the Turnstile Press, 10 Great Turnstile, London, W.C.1 (1s. 6d. monthly). The field which it covers is only beginning to be opened up, for a recognition of the need for further education too seldom troubled the education administrators of the last generation. The War did much to disclose the need and (what was more unexpected) did something to give it satisfaction. Many thousands of men and women in the Forces made their first acquaintance with 'serious pleasures', and have returned to civil life seeking the extension of that experience. The Education Act of 1944 envisaged a wide post-war enlargement of educational activity, and in its recent pamphlet, "Further Education", the Ministry set forth for the benefit of local education authorities many ideas and projects worthy of experiment and 